Check for updates

Hurley Group, London

clare.gerada@nhs.net

Cite this as: BMJ 2020;371:m4187 http://dx.doi.org/10.1136/bmj.m4187 Published: 03 November 2020

WOUNDED HEALER

\title{
Clare Gerada: GPs-scapegoats and saviours, heroes and villains
}

\section{Clare Gerada GP partner}

I'm proud to be a GP. It's one of the hardest and most worthwhile medical specialties. I've seen a rapid surge in GPs attending my practitioner health service (http://www.practitionerhealth.nhs.uk), making up nearly $60 \%$ of all new registrations. It's not hard to find a reason for this. In recent weeks we've been accused by patients, politicians, and NHS England of not being open and available for patients.

This recently culminated in a London practice having graffiti daubed on its walls, accusing it (in very abusive language) of not working. I'm sure I speak for others when I say that I find this extremely distressing and unfair. The idea that GPs are not working is completely unfounded: September figures show that we're consulting more, ${ }^{1}$ with more people, and at a greater level of complexity, than ever before. But our work is done behind closed doors, not in the full glare of TV cameras or newspaper reporters.

Of course, much of our work is now done online-back in March we moved almost all of our million consultations a day into the virtual world. We had to rapidly learn to use various platforms, learn the skills needed to consult remotely, and ensure that patients continued to receive essential care. We also had to deal with many of our staff being absent, moving to different sites or working at home.

Since I started as a GP more than 30 years ago, we've been simultaneously blamed and praised for the functioning of the NHS. We're seen interchangeably as scapegoats and saviours, heroes and villains. Politicians seem to think that we can magically make good the failings of the NHS and social care-that we can repair the fault lines created by decades of inequalities and underfunding of out-of-hospital services.

Unlike other specialists, we're identified for blame by name: "GPs are failing to ..." whereas with others it's the specialty: "Surgical lists/emergency department delays/cancer care waits ... get longer.” This makes it feel personal and adds to the despondency that many in my profession feel. I believe that singling out GPs runs deeper than the obvious (unfounded) view that we're not working. It's far more existential. One role for doctors-and I'd suggest more so for GPs, given our accessibility-is to contain patients' profound anxieties, particularly their fear of death. We've all been fed a daily diet of death for months now, and it's clear that GPs cannot protect our patients: even with our best efforts, more people will die as the virus continues to wreak its deadly havoc. If the first wave was one of solidarity and idealisation of the NHS (GPs included), the second wave is much more one of disappointment and facing the reality of what can be achieved.
Sadly, as society comes to terms with this change, GPs are caught in the crossfire. There's now a moral imperative to protect GPs from this unfounded criticism and to ensure that our role in keeping the NHS safe, good value for money, and accessible to all, is applauded.

Competing interests: See https://www.bmj.com/about-bmj/freelance-contributors.

Provenance and peer review: Commissioned; not externally peer reviewed.

Clare Gerada is chair of Doctors in Distress and medical director of NHS Practitioner Health. Her new book, Beneath the White Coat: Doctors, their Minds and Mental Health, is published by Routledge and can be purchased at https://www.routledge.com/Beneath-the-White-Coat-Doctors-Their-Minds-andMental-Health/Gerada/p/book/9781138499737. All royalties will be donated to Doctors in Distress.

NHS Digital. Appointments in General Practice September 2020. 29 Oct 2020. https://digital.nhs.uk/data-and-information/publications/statistical/appointments-in-general-practice/september-2020. 